Cahiers $d u$ MONDE RUSSE

\section{Cahiers du monde russe}

Russie - Empire russe - Union soviétique et États indépendants

52/2-3 | 2011

L'URSS et la Seconde Guerre mondiale

\title{
Local memory on war, German occupation and postwar years
}

An oral history project in the Donbass

Mémoire locale sur la guerre, l'occupation allemande et l'après-guerre. Un projet

d'histoire orale dans le Donbass

\section{Tanja Penter and Dmitrii Titarenko}

\section{CpenEdition \\ Journals}

Electronic version

URL: https://journals.openedition.org/monderusse/9348

DOI: 10.4000/monderusse. 9348

ISSN: $1777-5388$

\section{Publisher}

Éditions de l'EHESS

\section{Printed version}

Date of publication: 15 November 2011

Number of pages: $475-497$

ISBN: 978-2-7132-2352-5

ISSN: $1252-6576$

\section{Electronic reference}

Tanja Penter and Dmitrii Titarenko, "Local memory on war, German occupation and postwar years", Cahiers du monde russe [Online], 52/2-3 | 2011, Online since 12 September 2014, connection on 02 September 2022. URL: http://journals.openedition.org/monderusse/9348 ; DOI: https://doi.org/ $10.4000 /$ monderusse. 9348 


\section{LOCAL MEMORY ON WAR, GERMAN OCCUPATION AND POSTWAR YEARS}

\section{An oral history project in the Donbass}

This article presents the findings of a small oral history project carried out during the years 2001-2010 in the Eastern Ukrainian Donbass region. The Donbass, located in today's Eastern Ukraine, was until the 1960s the main coal region of the Soviet Union. ${ }^{1}$ Under Stalin's forced industrialisation of the 1930s, the region experienced an enormous economic development and population growth, and became a leading industrial centre and "showcase region of socialism." At the end of the 1930s,

1. See for the history of the Donbass (among others): Hiroaki Kuromiya, Freedom and Terror in the Donbas: A Ukrainian-Russian Borderland, 1870s-1990s (Cambridge: Cambridge University Press, 1998); Theodore H. Friedgut, Iuzovka and Revolution, Vol. 1, Life and Work in Russia's Donbass, 1869-1924; Vol. 2, Politics and Revolution in Russia's Donbass, 1869-1924 (Princeton: Princeton University Press, 1989-1994); Susan P. McCaffray, The Politics of Industrialization in Tsarist Russia: The Association of Southern Coal and Steel Producers, 1874-1914 (DeKalb: Northern Illinois University Press, 1996); Charles Wynn, Workers, Strikes and Pogroms: The Donbass-Dnepr Bend in Late Imperial Russia, 1870-1905 (Princeton: Princeton University Press, 1992); Lewis H. Siegelbaum, Daniel J. Walkowitz, Workers of the Donbass Speak: Survival and Identity in the New Ukraine, 1989-1992 (Albany, NY: State University of New York Press, 1995); Tanja Penter, Kohle für Stalin und Hitler: Leben und Arbeiten im Donbass 1929-1953 (Essen: Klartext, 2010). For the history of other parts of Ukraine under German rule in World War II see (among others) Karel C. Berkhoff, Harvest of Despair: Life and Death in Ukraine under Nazi Rule (Cambridge: Belknap Press, 2004); Dieter Pohl, Nationalsozialistische Judenverfolgung in Ostgalizien 1941-1944 (Munich: Oldenbourg, 1996); D. Pohl, Die Herrschaft der Wehrmacht: Deutsche Militärbesatzung und einheimische Bevölkerung in der Sowjetunion 1941-1944 (Munich: Oldenbourg, 2008); Thomas Sandkühler, "Endlösung" in Galizien: Der Judenmord in Ostpolen und die Rettungsaktionen von Berthold Beitz (Bonn: Dietz, 1996); Christoph Mick, Kriegserfahrungen in einer multiethnischen Stadt: Lemberg 1914-1947 (Wiesbaden: Harrassowitz, 2010); Andrej Angrick, Besatzungspolitik und Massenmord: Die Einsatzgruppe D in der südlichen Sowjetunion 1941-1943 (Hamburg: Hamburger Edition, 2003); Karl Heinz Roth, Jan-Peter Abraham, Reemtsma auf der Krim: Tabakproduktion und Zwangsarbeit unter der deutschen Besatzungsherrschaft 1941-1944 (Hamburg: Nautilus, 2011). 
the Donbass was the Soviet Ukrainian region with the highest industrialisation and urbanisation rates. The 1930s were formative for the development of a strictly hierarchical Stalinist social order and Stalinist work relationships. At the same time, the population's working and living conditions were extremely bad and comprised various violent measures - forced mobilisation of the workforce in the countryside, deportations of workers from the annexed Western Ukraine in 1939, or numerous political purges of workers and engineers. Nevertheless, the Stalinist regime succeeded in making many people believe in a "bright future" through various means of social mobilisation such as work stimulation (as for instance the Stakhanov movement) and propaganda. In many respects, during the first Fiveyear plans, the Donbass was a test field for the Stalinist regime's industrialisation, modernisation and political alignment efforts.

During World War II, parts of the Donbass were occupied over 22 months by the German Wehrmacht. The German occupation authorities undertook great efforts to rebuild and exploit the mines, which had been destroyed by the Red Army during retreat. Next to 1,800 German mining specialists, about 90,000 local miners - a quarter of them women - and around 20,000 Soviet prisoners of war were employed in the mines. Besides the workers who had to work for the Germans in the occupied territories, more than 350,000 Soviet citizens were deported from the Donbass as Ostarbeiter to Germany. In some cases, working in the Donbass mines could save local miners from deportation to Germany. An important role for the reconstruction of the mines and their successful exploitation was played by numerous local Soviet engineers who tried to improve their living conditions by collaborating with the Germans. Altogether, significant reconstruction work took place under German occupation and coal output increased. However, prewar production levels were only partly reached due to the immense destruction of the mines. The local population's work experience under German occupation bore many similarities with their earlier experience of the Soviet: forced recruitments and deportations were not totally new for the Donbass inhabitants - even if the degree of violence reached a new level under the Germans. Under German occupation, the population of the Donbass experienced extreme mass terror and violence. According to the Soviet Extraordinary Commission, in Donets'k (Stalino) region alone, mass graves with more than 323,000 victims (174,000 civilians and 149,000 Soviet prisoners of war) were discovered after the liberation. ${ }^{2}$ However, just as it was under Soviet rule, everyday life under the Germans cannot be characterised only by terror and violence. It was an effective combination of terror, incentives and propaganda. The Germans' "new order" was not so new for the civilian population of the region, and in many respects was in keeping with what they had experienced under Stalinist rule.

The experience of "forced labour" continued in the postwar Soviet Union. After the liberation by Soviet troops, forced labour and deportation in the

2. See the report by the Extraordinary Commission dated 30 May 1945 about German crimes in Stalino (Donets`k) region, in: GARF (Gosudarstvennyi arkhiv Rossiiskoi Federatsii), f. 7021, op. 72, d. 811,1. 12 f; Penter, Kohle für Stalin, 232 ff. 
postwar Donbass were concentrated in various ways. New large contingents of unfree workers were used as workforce in the reconstruction of the coal mines - for the most part German prisoners of war, so called "mobilised" German civilians, and repatriated Soviet citizens who had been deported to Germany as prisoners of war or Ostarbeiter. Thus, in postwar times, the Donbass resembled a large forced labour camp. At the same time, the Stalinist government had to recognize that the experience of German occupation had changed the attitudes of the population towards Soviet power. The war had given the returning Soviet citizens who had been deported to Germany and the civilians who had lived under German occupation the opportunity to look behind the "iron curtain" and get into contact with West European culture. In this respect, the experience of work under German rule played an important role. In postwar years, Soviet citizens who had worked for the Germans in the occupied territories or in Germany became stigmatised and discriminated against as traitors. This was part of an all-embracing new categorisation and hierarchical organization of the population by the State. The regime drew certain conclusions about the potential loyalty of Soviet citizens and their attitude towards the State on the basis of their specific wartime experience (as Red Army soldiers, inhabitants of the occupied territories, evacuees, repatriated Soviet prisoners of war, Ostarbeiter, or inhabitants of the newly annexed western territories and others). It punished disloyal and rewarded loyal behaviour. Furthermore, a broad, uncompromising purge was launched against the members of the Communist party who had stayed in occupied territory, and - in a much more pragmatic way - against skilled workers. The individual position inside the new social hierarchy went along with different freedom rights, food supply and general living conditions.

\section{Methodological considerations of the oral history project}

In our oral history project, we interviewed 58 local people about their experiences during the 22 months of German occupation during World War II and about their pre- and postwar lives. ${ }^{3}$ In Russia and Ukraine, oral history became a field of academic research only quite recently, after the collapse of the Soviet Union. Since the 1990s, several oral-history centres have been founded in St. Petersburg, Voronezh, Barnaul and Petrozavodsk. ${ }^{4}$ The Memorial centre of oral history and biography in Moscow has also played an important role. In Ukraine, the oral history discipline is still less institutionalized than in Russia, but the Ukrainian Oral History Association, based in Harkiv, was founded in 2006. Most of the oral

3. See Dmitrii Titarenko, Tanja Penter, "My perezhili okkupatsiiu..." : svidetel'stvuiut ochevidtsy, Donets'k (forthcoming in October 2012).

4. For an overview of oral history research in Russia see Irina Rebrova, "Oral History im heutigen Russland. Tätigkeitsfeld, Probleme und Perspektiven,” BIOS, 22, 2 (2009): 293-300. 
history projects in Russia and Ukraine focus on World War II and often deal with specific victim groups, mostly Jewish survivors and deported Ostarbeiter. ${ }^{5}$

For our oral history project in the Donbass, there were three methodological considerations that were of special importance. First, the regional approach of the oral history project: focusing on the population of the Donbass region enabled us to include and compare the diverse occupation experiences, memories and perceptions of different population groups. Unlike interview projects, which focus on single victim groups, our regional approach tries to give a more comprehensive perspective on the population's multiple and sometimes competing experiences of the occupation. For Ukraine, this regional approach is particularly interesting because it helps analyse the seemingly heterogenous regional memory cultures, especially the gap between East and West.

Historians have so far commonly accepted that the population in different historical regions of Ukraine (especially in the older Soviet territories of Central and Eastern Ukraine and in the Western Ukrainian territories annexed in 1939) experienced war and German occupation quite differently. This appears in heterogenous regional memory cultures, in which Soviet and national Ukrainian symbols and traditions intertwine in complicated ways. ${ }^{6}$ While in Central and Eastern Ukraine, the memory of the victory in the "Great Patriotic War" is still dominant and Red Army soldiers are perceived as liberators, in Western Ukraine many people primarily see the War as a fight of the Ukrainian Nationalist Organisation (OUN) against Soviet occupation. Generally, many different narratives about the history of Ukraine during World War II have existed so far.

Second, the focus on everyday life experiences under German occupation: in our oral history project, we tried to include the various everyday life and working experiences and the cultural perceptions of the population as well as experiences of terror, repression and violence under German occupation.

Third, the chronological frame of the project: the interviews followed a narrative biographical approach ${ }^{7}$ which included the interviewees' pre- and

5. See for example Alexander von Plato, Almut Leh, Christoph Thonfeld, eds., Hitlers Sklaven: Lebensgeschichtliche Analysen zur Zwangsarbeit im internationalen Vergleich (Wien, Köln, Weimar: Böhlau, 2008); G.G. Grinchenko, Nevygadane usni istorii ostarbajteriv (Kharkiv, 2004); Boris Zabarko, ed., "Nur wir haben überlebt": Holocaust in der Ukraine. Zeugnisse und Dokumente (Köln: Dittrich, 2004); P. Desbois, Der vergessene Holocaust: Die Ermordung der ukrainischen Juden. Eine Spurensuche (Berlin, 2009). For a local approach, focussing on the experiences of the occupation in a village in Pskov region see Zhanna Kormina, Sergei Shtyrkov, "Niemand und nichts ist vergessen. Die Okkupation in mündlichen Zeugnissen," Osteuropa, 55, 4-6 (2005): 444-461.

6. See Stefan Troebst, Wilfried Jilge, eds., "Divided Historical Cultures? World War II and Historical Memory in Soviet and post-Soviet Ukraine," Jahrbücher für Geschichte Osteuropas, 54, 1 (2006).

7. See for a narrative biographical interview approach Alexander von Plato, "Zeitzeugen und die historische Zunft. Erinnerung, kommunikative Tradierung und kollektives Gedächtnis in der qualitativen Geschichtswissenschaft - ein Problemaufriss," BIOS. Zeitschrit für Biographieforschung und Oral History, 13, 1 (2000): 5-29, here 21-25. For methodological considerations about oral history see Lutz Niethammer, "Fragen - Antworten - Fragen. Methodische Erfahrungen und Erwägungen zur Oral History," in L. Niethammer, A. von Plato, 
postwar experiences. During the interviews, we noticed that several interviewees established links between their experiences at different time periods. Besides, they tended, from their more total biographical perspective, to combine and correlate their experience of Nazi and Stalinist rule, which sometimes opened interesting comparative perspectives. In some cases, the subjective meaning of their war experience pervaded their biographical narrative. Historians, who have so far tended to study Stalinism and German occupation as separate topics, could learn from the witness accounts' more integrated perspective.

Finally it should be mentioned that our previous studies of the history of the Donbass from the 1930s to the 1950s on the basis of archival documents have enabled us to place individual narratives into context. ${ }^{8}$

The interviews were open and did not follow a firm set of questions. We normally interviewed people at home, to create as relaxed and pleasant an interview situation as possible. Concerning the selection of interviewees, we tried to embrace a wide range of experiences, including those of Jews and Non-Jews, men and women, children and adults, townspeople and country people, ordinary people, as well as resisters or deported Ostarbeiter. However, the selection of interviewees nonetheless remains a methodological problem and cannot be considered representative without constraints. We could not interview those who experienced the worst treatment under German occupation. Neither did we interview those who actively collaborated with the Germans. Besides, most of the available interviewees belonged to the younger generation, and had experienced German rule as young adults or adolescents, a fact which affected their perception of the occupation. ${ }^{9}$

\section{Memory accounts by former Soviet citizens}

According to Harald Welzer, witness accounts must be considered as target group related constructions, in which biographical experiences are each time newly formed and presented according to narrative and normative necessities as well as knowledge that was acquired later ${ }^{10}$. As the French sociologist

eds., "Wir kriegen jetzt andere Zeiten": Auf der Suche nach der Erfahrung des Volkes in nachfaschistischen Ländern (Berlin: J.H.W. Dietz, 1985), 392-445.

8. Penter, Kohle für Stalin und Hitler; Dmytro Tytarenko, "Presa schidnoï Ukraïny periodu nimets 'ko-fashysts 'koï okupatsiï jak istorychne dzherelo (1941-1943rr.)," doctoral dissertation, Donets'k, 2002.

9. A stronger interest in children's war experiences appeared in historical science only in the 1990s, following earlier studies in the fields of psychotherapy and gerontology. See among others: Margarete Dörr, Der Krieg hat uns geprägt: Wie Kinder den Zweiten Weltkrieg erlebten, (Frankfurt am Main: Campus, 2007, 2 vol.). For the former Soviet Union see Svetlana A. Aleksievich, Die letzten Zeugen: Kinder im Zweiten Weltkrieg (Berlin: AufbauTaschenbuch Verlag, 2005); "Kinder des Krieges," Bulletin des Deutschen Historischen Instituts Moskau, 3, (2009).

10. Harald Welzer, "Das Interview als Artefakt: Zur Kritik der Zeitzeugenforschung," BIOS. Zeitschrit für Biographieforschung und Oral History, 13, 1 (2000): 51-63, here 60. 
Maurice Halbwachs has shown, individual memory is always formed by social interaction and communication. It is constructed and confirmed by communication and exchange with other human beings on the one hand and by cultural interactions with media, material representations (texts, images, memorial sites) and symbolic practices (rituals, festivals) on the other. ${ }^{11}$ Interviews with witnesses can only to a very limited scale serve historians for the reconstruction of historical events. They mainly reflect how the interviewee perceives these historical events from today's perspective. This had led researchers to pay attention to the changes of individual and collective memory narratives in the course of time. ${ }^{12}$

It is also important to note that historical-political debates and political transformation processes, including the resulting changes in official historiography and official memory culture, influence private memory. Individual or family memories always correlate with the official historiography and memory culture of a society and the "master narrative" of a nation. ${ }^{13}$ In the countries of the former Soviet Union, several specifics must be noted: until the end of the Soviet Union, official remembrance policies were dominated by the mythification and overestimation of resistance and the partisan movement. At the same time, other aspects of the history of German occupation, for example the Holocaust, the question of collaboration, or forced labour imposed by the Germans on Soviet citizens, were suppressed and mostly excluded from any public discussion and collective memory culture. After the war, millions of Soviets who had lived under German rule were considered potential "enemies of the people," and for decades official questionnaires included the question whether the person has lived in occupied territory. During the interviews, we were surprised by the fact that special groups like deported Ostarbeiter and Soviet prisoners of war did not solely feel these discriminations and stigmatizations in postwar times. Many ordinary people who had just lived in occupied territory felt them as well. Many of the interviewees mentioned certain restrictions concerning education and job opportunities or travel abroad as well as a permanent mistrust by Soviet officials. One interviewee, who was 14 years old at the time of the German occupation of Stalino/Donets'k, recalled:

There was general mistrust towards the people who had stayed in occupied territory. We were like traitors. [...] The discrimination was not so open. It was more subliminal. But people felt that they were not full-fledged members of the

11. Maurice Halbwachs, Das Gedächtnis und seine sozialen Bedingungen (Frankfurt a.M., 1985); M. Halbwachs, Das kollektive Gedächtnis (Frankfurt a.M. 1985); Aleida Assmann, Der lange Schatten der Vergangenheit: Erinnerungskultur und Geschichtspolitik (Munich: C.H. Beck, 2006), 31-36.

12. See among others Piotr Filipkowski, "Polnische Lagernarrative in Zeit und Kontext," in Andreas Ehresmann, Philipp Neumann, Alexander Prenninger, Regis Schagdenhauffen, eds., Die Erinnerung an die nationalsozialistischen Konzentrationslager: Akteure, Inhalte, Strategien (Berlin: Metropol, 2011): 23-43.

13. Harald Welzer, ed., Der Krieg der Erinnerung: Holocaust, Kollaboration und Widerstand im europäischen Gedächtnis (Frankfurt a.M.: Fischer Taschenbuch Verlag, 2007), 17-18. 
collective. At my work place - I was a book keeper -, I always sensed that the attitude towards me was different from the attitude towards the evacuees. ${ }^{14}$

Discriminations against those who had worked for the enemy under the occupation were particularly severe. A woman who had worked in a briquette factory under German rule recalled her stressful experiences after the war:

When our troops arrived, we were terrorized because we had stayed in occupied territory. We were despised because we had lived under German occupation. Later, when I went to the social security office, I was told that I had worked for the Germans. Wouldn't they have worked for the Germans if a pistol had been held to their head? That's how it is. I am suffering terribly from this. Yes, I am even scared to remember these things. It was horrible. We were despised. Why? Were we criminals in any way? ${ }^{15}$

Of course there were gradual differences and the stigmatization and repression against millions of people could not be as severe as in the case of the forced labourers and prisoners of war, who were deported to Germany during the war and later repatriated. ${ }^{16}$ We also learned from some interviewees that a more pragmatic policy was pursued toward specialists who were needed for Soviet reconstruction, even if they had worked for the Germans. Nevertheless, these millions of Soviet citizens who had lived in occupied territory avoided to speak openly about their war experiences for decades. The families often were the only place where these things could be addressed. Many interviews give evidence that memories were passed on in the families from generation to generation. This is often expressed by remarks like "according to what my mother told me." Children and grandchildren picked up some elements of the memories of the older generation which they integrated into their own memories, thereby combining their own experiences with stories of their parents or grandparents. ${ }^{17}$ As several interviewees mentioned, their children asked them to commit their memories to paper so that they did not fall into oblivion. These stories were not to be told outside of the narrow private family circle, as one interviewee reported:

My grandmother always raised us to keep silent about the things which were spoken about at home. That is what she taught us. She was a very smart woman. ${ }^{18}$

14. Interview with Valentina I. (1927), recorded in December 2003 in Donets'k.

15. Interview with Vera P. (1922), recorded in June 2001 in Donets'k.

16. See for the repatriation of former forced laborers and POWs from Kiev: Tatjana Pastushenko, Das Niederlassen von Repatrierten in Kiew ist verboten... Die Lage von ehemaligen Zwangsarbeiter/innen und Kriegsgefangenen in der Ukraine nach dem Krieg (Kiev: IIU, 2011). Pastuschenko also uses oral history interviews in her innovative work.

17. The family constitutes an interface between individual and public memory. See for family memory, Halbwachs, Das Gedächtnis und seine sozialen Bedingungen, 203-242. For comparative research on family memory about World War II in different countries see Welzer, ed., Der Krieg der Erinnerung.

18. Interview with Boris R. (1933), recorded in February 2005 in Donets'k. 
After the collapse of the Soviet Union in independent Ukraine, a reinterpretation of Soviet historiography under new national paradigms took place. For the first time, Stalinist crimes could be researched and discussed. Several interviewees thus mentioned that they had only recently learned about them, and they incorporated this new knowledge in their accounts. Furthermore it might be of importance that the interview project coincided with the German Forced Labour Compensation Programmme during the years $2000-2006 .{ }^{19}$ In the post-Soviet states, compensation programmes have functioned as a catalyst for historical-political debates since the 1990s. As a result, former forced labourers were for the first time acknowledged as victims of National Socialism in their homeland societies. Numerous memoirs in prose or verse by former Ostarbeiter were published and theatre plays on the topic performed in the Ukrainian capital Kiev. At the same time, it must be noted that after the collapse of the Soviet Union, many elderly people in Ukraine suffered from poverty and very hard economic conditions. All these political, social and economic transformations surely influenced our interviewees' narratives and must be taken into account.

These historical and political factors may also explain why most of the interviewees showed a strong disposition and wish to talk about their personal experiences. Telling about the past often proceeds from an individual need for identity building. ${ }^{20}$ This seems especially true for post-Soviet societies, and one must take into consideration the fact that here, public memory accounts about the war may fulfil a special social purpose which has to do with social acknowledgement and status on the one hand and with search for orientation and community in times of disorder and confusion on the other.

\section{Memory and historical facts}

Does this mean that the interviews are rather useless for the reconstruction of historical events because of their subjective memory constructions? Again, the interview practice shows that in the countries of the former Soviet Union the situation seems to be special. Interviewees often recalled events that were not mentioned in Soviet historiography and official Soviet memory culture at all. More often than not, there exist no archival documents on these facts. Some accounts are in keeping with the new post-Soviet Ukrainian historiography, which after the collapse of the Soviet Union initiated a comprehensive revision of Soviet historiography, especially with regard to Stalinist crimes. However, the accounts sometimes come

19. An international project at Bochum University has researched this German compensation programme and its various results for the post-Soviet countries. See for the compensation of forced labourers in Ukraine the article by Julia Landau and for the compensation programme in Belarus and Russia the articles by Tanja Penter in the forthcoming volume (see note 3), Constantin Goschler, ed., Die Entschädigung von NS-Zwangsarbeit am Anfang des 21. Jahrhunderts, (Göttingen, 2012, Vol. 4), 104-279.

20. Assmann, Der lange Schatten der Vergangenheit. 
onto aspects of the history of the occupation that are still tabooed in Ukrainian historiography, as for example the question of collaboration. In these cases the interviews represent an impressive counter-narrative to the official version. This narrative has partly been passed on by family memory to the next generation.

In authoritarian societies, family memory may fulfil a special purpose due to the fact that individual memory stores facts which are absent from the allowed official memory culture. Memories which conflict with official memory are often confined to the privacy of family. But they still show the inner limits of totalitarian regimes. Thus, Peter Burke speaks of the "power of unofficial memory" which is hard to break, even by totalitarian regimes. ${ }^{21}$

At the end of our oral history project, we noted that the memories of the war generation can, at least to a limited extent, serve for the construction of a new postSoviet local and regional history of wartime years which otherwise would be totally lost due to the lack of other materials. As Aleida Assmann has noted quite judiciously, positivistic historiography reaches its limits where archival resources are lacking, and here oral testimonies can help overcome these boundaries. ${ }^{22}$ The capture of the city of Stalino/Donets'k by the Germans offers a vivid example. According to the official Soviet version, the city was captured on 26 October 1941 after several days of serious street battles, in which more than 50,000 German soldiers were captured, killed or injured. Contrary to that, several former citizens of Stalino reported in their interviews that the city was captured by the Germans on 20 October 1941 and almost without a fight. This version is confirmed by German documents. ${ }^{23}$

Moreover, the interviewees reported on other facts which are completely missing from the Soviet historiography on the war, such as the total destruction of local industries by NKVD and Red Army units during their retreat or the execution of local prison inmates. As several respondents recalled, NKVD units had executed the prisoners in Stalino. ${ }^{24}$ Among the prisoners were, apart from criminals, ordinary workers who had committed no other crime than coming late to work or leaving work without permission. They had been sentenced to prison under the Stalinist 1940 labour discipline law. All these prisoners were shot by the NKVD during retreat. Other interviewees reported about the planned destruction of the coal mines:

They came to blow up the mine. A command of sappers arrived and they blasted away at the mine. At that time people ran to the mine, everybody came to the mine. We won't allow you to destroy everything. What shall we live on? You will leave and what shall we live on? Shall we starve? [...] There was such panic

21. See Peter Burke, "Geschichte als soziales Gedächtnis," in Aleida Assmann, Dietrich Harth, eds., Mnemosyne: Formen und Funktionen der kulturellen Erinnerung (Frankfurt a. M.: Fischer Taschenbuch Verlag, 1991), 289-304, here 300.

22. Assmann, Der lange Schatten der Vergangenheit, 47.

23. RGVA (Rossiiskii Gosudarstvennyi Voennyi Arkhiv, f. 1458, op. 40, d. 221, 1. 280; RGVA, f. 1458, op. 40, d. 221, 1. 280; Bundesarchiv-Militärarchiv (Freiburg), RH 24, B1. 49.

24. Interview with Alexei A. (1923) recorded in July 2009 in selo Novonikolaievka/Donets'k region and Ivan S. (1927), recorded in October 2004 in Donets'k. 
and they wanted to prevent the explosion of the mine. But then there was an encirclement. All the people were dispersed, the mine was blown up and two days later the Germans arrived. ${ }^{25}$

The huge destructions of the Donbass coal mines and the shootings of prisoners before the Red Army's retreat are confirmed by German documents. ${ }^{26}$

The destruction of grain by the Red Army during retreat was a common theme in the accounts. The burning of the grain was perceived by many interviewees as a symbol of the fact that the population was virtually left to its own devices and exposed to hunger and starvation. Stalin's “burned earth" policy and the significant destruction of the Donbass coal mines was a taboo topic in Soviet times. The Soviet side on its part had always emphasized the large-scale destruction wreaked by the Germans during their retreat from Donbass two years later.

\section{First results of the oral history project in the Donbass}

In this review of the main findings of our oral history project, we will pay special attention to the question of how the interviewees dealt with German rule in relation to pre- and postwar Stalinist rule and especially how they dealt with Nazi and Stalinist crimes. We will also analyze how respondents depicted the Germans and local collaborators.

Firstly it can be noted that most of the interviewees perceived the relatively short period of German occupation as being of central importance in their lives. This is for example expressed in statements like: "It seems to me that under the occupation half of my life passed by. I remember every single day. My God, what a horrible time it was!" ${ }^{27}$ Moreover, the memories are often impressively detailed. Many interviewees remembered the first names of Germans they came into contact with. Others could still recall German songs which they learned from the occupiers, and sometimes started to sing them during the interview.

The subjective importance of the relatively short period of the occupation for many interviewees might be explained by the general importance of youth experiences for the formation of a person's identity. According to the sociologist Karl Mannheim, the experiences of human beings between the age of 12 and 25 remain constitutional for the whole process of personality shaping. Therefore, members of a historical generation share a common identity with regard to convictions, attitudes, worldviews, social values and cultural patterns of interpretation. ${ }^{28}$ However, the

25. Interview with Viktor D. (1928), recorded in April 2004 in Donets'k.

26. See Penter, Kohle für Stalin und Hitler, $179 \mathrm{ff}$.

27. Interview with Maia P. (1925), recorded in January 2005 in Donets'k.

28. Karl Mannheim, "Das Problem der Generationen," in Kurt H. Wolff, ed., Karl Mannheim, Wissenssoziologie: Auswahl aus dem Werk (Berlin, Neuwied: H. Luchterhand, 1964), 509-565; Assmann, Der lange Schatten der Vergangenheit, 26. 
detailed and minute memorization might also be explained by the extraordinary singularity of the experience for the interviewees.

Moreover we must notice that today, the historical meaning and importance of German occupation is seen quite differently in the memory cultures of the various occupied countries in Europe. ${ }^{29}$ The relative importance of the German occupation for former Soviet citizens might also be explained by the fact that for many of them - due to the iron curtain - it was their first (and sometimes only) contact with Westerners and in so far (at least for some of them) also constituted an important cultural experience. Moreover, it must be taken into account that for decades, most of the interviewees had had no opportunity to process their wartime experiences or to talk openly and publicly about them. This, too, might possibly explain the generally significant importance of that time period for the interviewees and their strong wish to talk about it. For the former stigmatized groups such as forced labourers, telling about their past fulfilled functions of social acknowledgement as victims of National Socialism, as one former Ostarbeiter recalled:

Of course people's attitudes have changed. Now we are acknowledged by everybody. This year, our raion celebrated its 85 th anniversary. We were invited to the celebration. I addressed the audience, spoke about Germany. With tears in my eyes, I expressed thanks for being accepted into society. Before that, it was as if we were not part of it. ${ }^{30}$

At the same time, it must be noted that the reactions of Ukrainian society towards the compensation programmes were sometimes quite ambivalent. Several former Ostarbeiter recalled that they experienced jealousy and resentment from their neighbours, especially from those who lived under German occupation and did not receive any compensation. The payment programmes thus created new social tensions and competition among the war generation. Many elderly people are still convinced that most Ostarbeiter went to Germany voluntarily. And the official memory book of the victims of the Second World War in Donets'k region ("Kniga Pamiati Ukrainy"), which is financed by the Ukrainian government, has not to this day mentioned the deported Ostarbeiter at all. ${ }^{31}$

A further observation must be added here. When we analyzed the interviews, we sometimes noted huge differences in content and form between the narratives.

29. See for Norway, Denmark, the Netherlands, Serbia and Croatia, Harald Welzer, Claudia Lenz, "Opa in Europa. Erste Befunde einer vergleichenden Tradierungsforschung," in Welzer, ed., Der Krieg der Erinnerung, 7-40.

30. Interview with Alexandra B. (1926), recorded in July 2009 in Zaitsevo, raion Artemovsk, Donets'k region.

31. See for this question in detail, Dmytro Tytarenko, “'Deutsches Geld' für die Zwangsarbeiter. Die Reaktionen der Bevölkerung des Gebiets Donezk auf die Auszahlungen der Stiftung 'Erinnerung, Verantwortung und Zukunft',' in Goschler, ed., Die Entschädigung von NS-Zwangsarbeit, 281-306. 
For instance, the narratives of former members of resistance movements, who already in Soviet times could at least partly talk about their war experiences publicly, often seemed to follow a certain pattern. We got the impression that these interviewees had repeated their narratives many times, for example in forms of ritualized public accounts for school children or inside their former resistance circle. In contrast with the stories of other groups of the war generation, theirs were to a great extent part of the official Soviet memory culture. Frequent repetition had given these memories a more stable form and structure. Even in post-Soviet times, the partisans and resistance fighters still perpetuate their old Soviet memory narratives, which seemingly form a strong part of their identity. Compared to this, the narratives of other interviewees, non-resisters, appeared to be much more open, fragmentary and fragile and did not follow these patterns. In some cases, those witnesses had the possibility to formulate a coherent narrative of their life experiences for the first time. Surprisingly, in both cases the accounts were sometimes accompanied by emotional outbreaks.

\section{Experiences under the occupation}

Looking at everyday life under German rule, it becomes clear that terror was one of the main experiences of the population. Some of the interviewees described the feeling of being at the absolute mercy of the occupying Germans: "We were completely without any rights. We had no rights or laws. The Germans were the masters and absolute rulers. And we were slaves, real slaves." 32

However, terror was never absolute, and the interviewees mentioned other spheres of contact and interrelation between Germans and locals in which experiences were different. In several respects, the experience of work was crucial in building the identity - and loyalty - of the population before, during and after the German occupation. Under German rule, about 90,000 Soviet coal miners and 20,000 Soviet prisoners of war worked under the supervision of 1,800 German mining specialists in the Donbass coal mines. Apart from that, more than 330,000 Ostarbeiter were deported to Germany. ${ }^{33}$ These numbers show that many of the Soviet workers had direct contact with German supervisors. Experiences at the workplace were quite different. Working together, local workers and German supervisors sometimes even formed friendly relations, as a former coal miner recalled:

Our Germans were coal miners. These Germans, who worked together with us miners, did no harm to anybody. Because they understood us and even told us that they were workers just like we were. ${ }^{34}$

32. Interview with Zoia Tch. (1929), recorded in February 2005 in Donets ${ }^{\prime k}$.

33. See Penter, Kohle für Stalin und Hitler.

34. Interview with Valentin N. (1926), recorded in June 2001 in Donets'k. 
In some cases, working in the local mines saved the workers from forced deportation to Germany, as several interviewees reported..$^{35}$ The meaning of these contacts for the interviewees was evidenced by the fact that 60 years later, some still remembered the first names of some German workers and the places in Germany that they came from. Other interviewees remembered the brutality of German supervisors and their contemptuous treatment of the workers, as for example a woman who worked in the coal mines as a 15-year old girl and was publicly beaten by a German supervisor for leaving work without permission. ${ }^{36}$ Sometimes, workers who refused to work were even executed by the Germans. ${ }^{37}$ Most interestingly, several interviewees experienced their work under German rule as especially orderly and organized some of them even referred to a certain German pedantism - and compared it to their much more undisciplined and chaotic work experiences before and after the war. ${ }^{38}$ The "work for the enemy" was a central experience which the majority of the population shared and which has been understudied so far with regard to its consequences for postwar developments. ${ }^{39}$

Concerning the German Vernichtungspolitik ("policy of extermination"), it is striking that the murder of prisoners of war in occupied Donbass was more ingrained in memories than the murder of Jews. This is due to the fact that the execution of Soviet prisoners of war took place in the Donbass on a much larger scale and during a longer time period and was quite visible to the local population. According to reports of the Extraordinary Commission, around 150,000 Soviet prisoners of war died in German camps in the Donbass. The number of Jewish victims in the Donbass was considerably smaller and accounted for approximately 18,000 (according to estimates). ${ }^{40}$ The "Jewish question" was resolved by the Germans much faster and less visibly.

In many interviews we saw that locals tried to provide the starving prisoners of war with food, thus taking the risk of being executed by German officers:

The prisoners of war died from hunger and in the open air [...] At that time, seeing this, people understood who the Germans were and how they behaved. Here they showed their real essence. Officially it was not allowed to help the prisoners of war $[\ldots]$ but the people threw whatever they could behind the barbed-wire fence. [...] But the Germans punished this strictly. They drove them away from the fence, beat and humiliated them. ${ }^{41}$

35. Interview with Valentina Tch. (1921), recorded in May 2004 in Donets'k.

36. Interview with Aleksandra P. (1927), recorded in June 2001 in Donets'k.

37. Interview with Viktor S. (1929), recorded in October 2004 in Donets'k.

38. Interview with Valentin N. (1926), recorded in June 2001 in Donets 'k.

39. Tanja Penter, "Die Ukrainer und der 'Große Vaterländische Krieg': Die Komplexität der Kriegsbiographien, in Andreas Kappeler, ed., Die Ukraine: Prozesse der Nationsbildung (Köln: Böhlau, 2011), 335-348.

40. For a detailed analysis, see Penter, Kohle für Stalin und Hitler, $234 \mathrm{ff}$.

41. Interview with Viktor Z. (1927), recorded in March 2004 in Mariupol'. 
It has been argued that if the Germans had not prevented the population from supplying the prisoners of war with food, there would have been considerably less starvation among them. ${ }^{42}$

It is impossible to quantify the help and support that the local population gave to the prisoners of war. It seems to us, however, that the narratives may have fulfilled another purpose, that of helping postwar society compensate for subconscious feelings of guilt. In this respect, the Soviet prisoner of war motive bears several parallels with the widespread German accounts about the sandwiches that the German population allegedly gave to the deported Ostarbeiter.

Only a limited number of interviewees mentioned similar support for their Jewish neighbours, which might partly be explained by the fact that those who helped Jews took the risk of being sentenced to death by the Germans. Nevertheless, some locals helped Jews by hiding them in their homes.

The attitudes of non-Jews towards their Jewish neighbours varied, as one interviewee recalled:

Some openly hated them [the Jews], others remained silent. Well, firstly not everybody knew about it [the execution of Jews]. [...] And then, when they learned about it, those who hated them were pleased about it. But others mourned because they were human beings. It was rather varied. ${ }^{43}$

It must also be noted that official remembrance policies and schoolbooks in postSoviet Ukraine still treat the Holocaust as a rather marginal event and do not integrate it into national Ukrainian history. As a result, the dark side of that period is excluded from the national narrative, and so is the rescue of numerous Jews by their courageous Ukrainian neighbours. In this respect, Ukrainian public memory culture seems, at least to some extent, to perpetuate old Soviet remembrance policies which suppressed the Jewish memory of the Holocaust. ${ }^{44}$

\section{Depicting the German occupiers}

Regarding the general depiction of the Germans made in the narratives, it is striking that there are as many stories about "good Germans" as stories about "bad Germans," independently of the fact whether the interviewer was German or Ukrainian. Even though racism, cruelty and a feeling of superiority were common characterizations of the Germans in many interviews, we also heard

42. Karel C. Berkhoff, "The 'Russian' Prisoners of War in Nazi-Ruled Ukraine as Victims of Genocidal Massacre,” Holocaust and Genocide Studies, 15 (2001): 1-32.

43. Interview with Boris R. (1933), recorded in February 2005 in Donets'k.

44. See Wilfried Jilge, "Competing victimhoods - Post-Soviet Ukrainian Narratives on World War II," in Elazar Barkan, Elizabeth A. Cole, Kai Struve, eds., Shared History - Divided Memory: Jews and Others in Soviet-Occupied Poland, 1939-1941 (Leipzig: Leipziger Universitätsverlag, 2007), 103-133, here 115-119. 
many stories about German soldiers who provided locals with food, showed them photographs of their children or gave Christmas presents to them. When the army units moved further on, farewell photographs were taken and local women cried. ${ }^{45}$ Women who accommodated officers were looked at with jealousy, because, in return for sexual favours, these officers normally provided the whole family with food. ${ }^{46}$ Many interviewees mentioned the contacts with German soldiers and officers who were quartered in their homes, as well as barter deals, black markets, prostitution, and relationships between Soviet women and Germans, which interviewees did not generally condemn, but attributed to the hard living conditions of women. Others remembered cultural experiences with German cinema - Soviet people often perceived the German entertainment films as immoral.

The Jewish population's much too positive picture of the Germans before the occupation, which probably resulted from experiences from World War I, turned out to be fatal. Thus, one Jewish respondent mentioned that positive expectations of the Germans prevented some Jewish families from evacuating. He recalled:

When the period of occupation came closer, my father said: "I know the Germans quite well. I have talked to them. They are a quite cultured and hard-working people. I don't believe what is written in the press. We will stay here. [...] That is all communist propaganda. That cannot be true. The Germans are orderly, respectable people." ${ }^{47}$

The interviewee's family, despite this fatal misjudgment, wondrously managed to survive the occupation with fake Russian passports.

All these stories show that the range of memories and narratives is quite wide. While official Soviet propaganda and historiography propagated a rather dehumanized picture of the enemy, individual memories recall various human relationships between occupiers and the occupied population, including hatred, friendship and sometimes even love. Thus, an interviewee who experienced the war as an eight-year-old boy recalled:

The best thing in the time of occupation was when this curious, unexpected friendship with this German driver developed, and he gave me a pocket knife as present. ${ }^{48}$

But in another situation, the same interviewee reported about the feeling of mortal fear when another German had beaten him brutally. These everyday relationships

45. Interview with Nina K. (1931), recorded in December 2004 in Konstantinovka.

46. Interview with Lev V. (1924), recorded in May 2005 in Donets’k.

47. Ibid.

48. Interview with Boris R. (1933), recorded in February 2005 in Donets'k. 
between occupiers and occupied as well as their mutual perceptions need to be studied much more carefully.

Many interviewees have also mentioned the German strict order (Ordnung), punctuality and cleanliness. According to one respondent, even the inside of a German tank was clean and tidy. ${ }^{49}$ Several interviewees believed that under German rule, criminality was successfully eliminated. At the same time, several interviewees were shocked by the cruelty of German officers who punished child thieves by chopping off their hands,,$^{50}$ which they explained with the German aversion against theft.

Others remembered the Germans' fine uniforms and professional equipment with admiration and counterposed it to the rather poor view of the Red Army soldiers. A woman even called the Germans "a beautiful nation." ${ }^{51}$ Another recalled:

They were very accurate. They took care of their external appearance. Even though I was still young, I noticed that. Even if it was wartime and they were in a foreign country, they took great care in their appearance..$^{52}$

Many contemporary witnesses noticed a particular honesty and love of order in the Germans, in contrast to their Italian and Rumanian allies who were purported to be thieves. Even though the German occupying forces took away all of the population's possessions, they did this, according to one interviewee,

not like thieves. [...] They took everything they liked directly in front of the population, because they were convinced that it was supposed to be like that and it was according to the rules.

Thus, in retrospect, the interviewee considered the Germans' lacking awareness of wrongdoing in a positive way and as particularly honest and orderly behaviour. The Italian and Rumanian soldiers, however, were often stereotyped as "thieves and robbers." At the same time, it can be observed that the perception of the Italian soldiers was often generally more positive than that of the German ones The Italians were apparently regarded as less violent, always cheerful, fond of children and very religious. They allegedly had a strong weakness for the local women. This - on the whole more positive - perception can presumably be explained by their lower level of indoctrination as well as the fact that they, as a rule, did not take part in punitive measures against the population.

49. Ibid.

50. Interview with Evgenii F. (1931), recorded in April 2005 in Donets'k; Interview with Viktor S. (1929), recorded in October 2004 in Donets'k.

51. Interview with Nina K. (1931), recorded in December 2004 in Konstantinovka.

52. Interview with Taina C. (1932), recorded in July 2003 in Donets'k. 
Most interviewees perceived the local policemen and collaborators as even worse than the German occupiers. Thus the interviewees made statements like the following:

The Germans were better than our policemen - those bootlickers that tortured us. They were worse than the Germans. They were Germans after all, the others were ours..$^{53}$

Or:

All the repulsion, all the repulsive behaviour came from the side of the local inhabitants, from those who wanted to serve the Germans. For them, denouncing somebody was a heroic deed. ${ }^{54}$

Local collaborators were said to be particularly cruel and corrupt. With them, the population was able to buy itself off with money and goods, whereas, in several respondents' views, "a German would not have got involved with that kind of thing." ${ }_{55}$ Several interviewees reported that local policemen simply took food and other property from the population. For example, they took away the bread people had traded for goods in villages several walk days away. Here, many interviewees supposed that the local collaborators had different motives for their actions, from hatred toward the Soviet authorities that was often based on the repressions suffered in the 1930s to a fight for bare survival. A few interviewees added that even among the collaborators, there were some who tried to act for the good of the population. ${ }^{56}$

Several interviewees reported about postwar criminal convictions of local collaborators whose logic evaded them. Thus, some who had behaved in a particularly gruesome way towards the population stayed at large, whereas others were sentenced to long periods in camps. ${ }^{57}$ What is interesting here is that many local inhabitants were aware of those postwar trials, which were mostly closed to the public and rarely reported on by the press. Locally, this sort of information quickly spread among neighbours by word of mouth. The participation of local witnesses in the trials may have played a role as well. While there has been at least a limited local exchange about collaboration among the people here, the topic until the recent past - has been for the most part excluded from the official media coverage and remembrance culture regarding World War II. ${ }^{58}$

53. Interview with Nikolai T. (1925), recorded in April 2004 in Donets'k.

54. Interview with Lev V. (1924), recorded in May 2005 in Donets`k.

55. Interview with Evgenii F. (1931), recorded in April 2005 in Donets'k.

56. Interview with Ivan K. (1931), recorded in November 2003 in Donets’k.

57. Interview with Liliia K. (1926), recorded in January 2005 in Donets'k.

58. Tanja Penter, "Local Collaborators on Trial. Soviet War Crimes Trials under Stalin (1943-1953)," Cahiers du Monde russe, 49, 2-3 (2008): 341-364. 


\section{Interrelating experiences under Stalinist and Nazi rule}

Interestingly, many interviewees - though this was not an explicit question mentioned crimes of the Stalinist regime next to German crimes and drew certain comparisons between Nazi and Stalinist rule. Among the Stalinist crimes, many interviewees especially mentioned the shooting of demonstrating workers who protested against the destruction of the coal mines during the Red Army's retreat; the execution of several hundred prisoners by the NKVD, the shootings of supposed collaborators by the Red Army and the NKVD after liberation, the Soviet bombing of civilian houses in occupied territories, the manmade hunger of 1932-1933 or the Great Terror of 1937-1938. Several interviewees referred to new Ukrainian publications about the Stalinist crimes of the 1930s and mentioned that they only recently learned about them. Here the influence of post-Soviet media publications on individual memory narratives becomes visible.

A few interviewees quite openly admitted that part of the population in the occupied territories welcomed the German occupiers with bread and salt and had high expectations of them (which of course were soon disappointed):

The people were waiting for the Germans because they wanted a change. Here, shootings and repressions took place before the war, in 1937 and $1938 .{ }^{59}$

Others talked about the indifference of Soviet citizens towards the changing powers and emphasized that, from the perspective of their everyday life experience, there were few differences between Stalinism and National Socialism. In some respects, the Germans even appeared in a more positive light than the Stalinist regime. One interviewee stated:

I did not see that the fascists beat their own people. The Germans only murdered foreigners, but ours murdered their own people. So what is better - fascism or communism $?^{60}$

To some interviewees, German occupation in retrospective seemed to present a real power alternative, even somehow, a lost historical chance. Therefore, statements like the following appeared in some of the interviews:

If the Germans had treated the Russian people better, they probably would have won the war. [...] If there had not been this cruelty and roughness, everything would have turned out differently. Hitler was such an idiot. If he had not morally disappointed the people so much, he would have won. That's for sure. ${ }^{61}$

59. Interview with Ivan S. (1925), recorded in October 2004 in Donets ${ }^{\prime k}$.

60. Ibid.

61. Interview with Nikolai O. (1931), recorded in July 2003 in Donets'k. 
Another interviewee mainly attributed the Germans' failure to their inhuman treatment of the prisoners of war. He concluded that they would have won the war if they had treated the prisoners of war better:

Then they would not have had any enemies in the occupied territories. Then they would have been able to champion their cause on and on and on. They might have even beaten the Americans and totally plundered America. Then they would have had everything. But they made this mistake. ${ }^{62}$

\section{Refiguration of memory - a re-evaluation of history?}

How do narratives about good Germans fit German hunger policies, deportations, mass graves and - according to the Soviet Extraordinary Commission accounts - more than 320,000 dead civilians and Soviet prisoners of war in the Donbass? Our thesis is that after the collapse of the Soviet Union and the following political, economic and social transformations in certain groups of the war generation, a refiguration and re-evaluation of the German occupation in World War II took place. ${ }^{63}$ The horrors of the occupation were put into perspective with regard to the crimes of Stalinism that Ukrainians had learned about in the media after the collapse of the Soviet Union on the one hand - and with regard to the stressful political, economic and social transformations on the other hand. It is also possible that the two German compensation programmes for the victims of National Socialism, especially forced labourers in Ukraine, Russia and Belorussia, have contributed to improving the Germans' image among the war generation.

It must be noted that during the interviews, several interviewees suddenly switched from their reports about war times to their poor living situation of the time, thereby creating a sort of implicit connection between these two very different experiences. This subjective interrelation of the two experiences becomes obvious in statements like the following:

These were interesting years. Very interesting. And now I am sometimes thinking how easy it was at that time. ${ }^{64}$

One interviewee stated:

Perestroika has been going on for a long time. The Soviet Union just fell to pieces under our eyes. Back then we had a government and then suddenly it was

62. Interview with Ivan S. (1925), recorded in October 2004 in Donets'k.

63. The connection between war memories and actual self-perceptions and life perspectives has long been recognized. See for example Robin Lohmann, Gereon Heuft, "Autobiographisches Gedächtnis und aktuelle Lebensperspektive im Alter. Eine empirische Studie biographisch rekonstruierter Kriegserfahrungen," BIOS, 9, 1 (1996): 59-73.

64. Interview with Iakov G. (1924), recorded in October 2001 in Donets'k. 
no more. Who is ruling now, we don't know. Where we are going now, we don't know either. ${ }^{65}$

Statements like these show the deep uncertainty and disorientation of the war generation. After the collapse of the Soviet Union, many elderly people in Ukraine experienced a decline in their living conditions and general status in society. ${ }^{66}$ Sometimes, the new debates about remembrance policies in independent Ukraine were quite confusing for the older generation, as one interviewee recalled:

I must tell you that I sometimes sleep very badly at night. Quite often, everything is mixed up in my head. You know, the years and times mix up when I read in the newspapers and journals that $[. .$.$] that war was neither great nor a patriotic$ war, as many people write nowadays ${ }^{67}$

One interviewee even came to a surprising comparison between the experience of German occupation and the experience of post-Soviet transformations and uttered:

The end of communism was more frightening than fascism. ${ }^{68}$

These statements indicate that the interviewees have experienced several more or less traumatic situations, and the period of German rule was only one of them. No less stressful for some of the interviewees were the experiences under Stalinist rule and the latest transformations after the end of the Soviet Union. Interviewees tended to interrelate all these different experiences in their narratives.

Some interviewees in retrospective glorified the solidarity of Soviet wartime society:

People were totally different. They shared everything. [...] People were much more good-hearted than today. They were poor, but morally they were totally different people. ${ }^{69}$

This perception is in conflict with the common practice of denunciation under German occupation reported by several interviewees:

Denunciation was everywhere. If somebody did not like someone else, he just wrote a note and the police took the person away and started to torture

65. Interview with Grigorii T., recorded in October 2004 in the village Novobakhmutovka, Donets'k region.

66. Aleksandr Sidorenko, "Faktizität und Geltung. Altenpolitik im postsowjetischen Raum," Osteuropa, 60, 5 (2010): 131-141.

67. Interview with Zoia Tch. (1929) recorded in February 2005 in Donets'k.

68. Interview with Boris R. (1933), recorded in February 2005 in Donets'k.

69. Interview with Zoia Tch. (1929), recorded in February 2005 in Donets’k. 
them. [...] Everybody wrote lies about everybody. Because there had been an announcement: denouncing a partisan was rewarded with a cow. ${ }^{70}$

Another interviewee recalled:

Somebody wanted an apartment or house or something like this. He wrote a denouncement. Without any proof the person was arrested and put in prison. That's what it was like at that time. ${ }^{71}$

We can thus conclude that at least in some interviews a certain refiguration of memory and a more positive evaluation of the period of German occupation and the German occupiers (in combination with the forgetting of German crimes) has taken place. It is also noticeable that some interviewees who were deported as forced labourers to Germany and received a compensation payment also had a more positive image of the Germans today, as one interviewee mentioned:

It was Germany that gave me money. Ours would never have given me anything. [...] No, I cannot say that I am resenting the Germans, only the Gestapo people who beat me with a whip. ${ }^{72}$

Some of the former Ostarbeiter even recalled their experiences with forced labour in Germany in a rather positive way. One interviewee said that in Germany, he had "learned to work well and conscientiously." " Another mentioned: "I was there and at least I saw something from the world. I saw how good people can live." ${ }^{\prime 4}$

This refiguration of memory seems to be connected with the various painful transformation processes which took place in Ukrainian society after the collapse of the Soviet Union. And in this respect, it shows the various new social and cultural interactions and communications as well as the influence of media and official remembrance policies in independent Ukraine. It also indicates, to some extent, how the war generation coped with these various changes. There seems to be a correlation between the lack of orientation, social status, and poor living conditions of many elderly people in post-Soviet Ukraine ${ }^{75}$ and their accounts about the past. And it may not be accidental that in times of felt disorder and disorientation, some

70. Interview with Evgenii F. (1931), recorded in April 2005 in Donets'k.

71. Interview with Boris R. (1933), recorded in February 2005 in Donets'k .

72. Interview with Maruia B. (1923), recorded in July 2009 in Zatish'e, raion Volnovakha, Donets'k region.

73. Interview with Efim G. (1933), recorded in August 2010 in Donets'k.

74. Interview with Olga U. (1926), recorded in July 2009 in Belogorovka, raion Artemovsk, Donets'k region.

75. For the bad economic situation of the war generation in Ukraine, Belorussia and Russia see the volume "Altersbilder. Kriegserinnerungen, Demographie und Altenpolitik," Osteuropa, 60, 5 (2010). 
interviewees recalled the cruel but strict and seemingly reliable orderliness under German occupation in a positive way.

At the same time, we must also consider the possibility that these perspectives on the past may be specific to those who did not suffer most under the German terror regime. They may also be specific to the younger generation, who experienced the war as children and young adults. Last, we do not know whether these apparently new narratives about the occupation are really the result of recent refigurations of memory after the collapse of the Soviet Union, or have in fact existed for decades inside the families and can only today be openly expressed by the interviewees. We must also bear in mind that a more positive picture of the Germans had already been propagated by the Soviet media since the 1950s with regard to the new "socialist brothers" in the GDR. However, detailed research on this question is still lacking.

\section{Conclusion}

In Ukraine, the stormy period of transformation after the end of the Soviet Union was a period of changes in remembrance policies and official memory culture. Since Ukrainian independence, the memory culture about the Second World War has changed significantly. At first, starting in the early 1990s, Ukrainian national historians interpreted the War under a new national paradigm. The underground fight of the Organisation of Ukrainian Nationalists (OUN) received special attention. However, the question of Ukrainian collaboration and participation in the execution of Jews has remained a blemish and a taboo topic in historiography. ${ }^{76}$ The often mentioned split between memory culture on the war in Eastern and Western Ukraine seems to be only partly true today. In fact, the Ukrainian memory landscape has become much more pluralistic and diverse in the last years and cannot be reduced to Eastern Ukrainian "Soviet" and Western Ukrainian "nationalist" memories. ${ }^{77}$ This finds confirmation in our oral history project in the Donbass. The project has discovered local counternarratives about war and postwar experiences which are counterposed to the former official Soviet memory culture. Whereas such counternarratives might be expected in Western Ukraine, it may be surprising to find them in the Eastern Ukrainian Donbass region, which had always been a showcase for Stalinist industrialisation and a traditional stronghold of Soviet power, and counted a large Russian minority among its population. This indicates that the often described "war of memory" between Eastern and Western Ukraine does not exist any more.

The same observations have been made by researchers studying post-Soviet memory cultures in the Western Ukrainian city of Lviv. While a heroic memory of

76. Wilfried Jilge, "Nationalukrainischer Befreiungskampf. Die Umwertung des Zweiten Weltkriegs in der Ukraine," Osteuropa, 58, 6 (2008): 167-186.

77. Andrij Portnov, "Pluralität der Erinnerung. Denkmäler und Geschichtspolitik in der Ukraine,” Osteuropa, 58, 6 (2008): 197-210. 
Ukrainian nationalism in the Second World War dominated the post-Soviet memory culture in Lviv during the first years after the collapse of the Soviet Union, today a growing local public sphere, alternative discourses and local influences on memory culture have come to the fore in the city. ${ }^{78}$ Thus, it seems that throughout occupied Ukraine, people have shared everyday life experiences under Nazi and Stalinist rule which today might be part of a more integrated memory culture.

Let us now draw attention to one other observation about what we can learn from the interviews: last but not least, they show us the complexity of wartime biographies and experiences which often do not fit into narrow frames of interpretation. Research on the wartime Soviet Union was for decades dominated by a certain vision that reproduced the manichaeistic pattern of Soviet historiography and divided Soviet citizens into nationalists, collaborators, resisters or victims. Moreover, all of these phenomena were mostly studied separately. We learn from the interviews that loyalties were rather fragile and changed quite frequently during the war. The sharp lines of definition and categorisation which historians (as well as the architects of compensation programmes) have created in dealing with the past do not fit wartime reality. Many people collaborated at one time and participated in Soviet resistance or fought in the Red Army at another. There were no clear lines between collaboration and resistance, but rather moral grey zones. The different phenomena were in fact much more dynamic and intermingled than historians have noticed so far. Experiences of the occupation were diverse, and besides, experiences of terror and violence also included cultural and working experiences as well as various personal relationships with the German enemy. Therefore we would argue for much more integrated research approaches trying to combine the wide range of different wartime experiences. In that respect, interviews with witnesses can be particularly helpful.

\section{Helmut-Schmidt-University Hamburg}

penter@hsu-hh.de

Donetsk Institute of Law

titarenko_tit@ukr.net

78. See Tarik Cyril Amar, "Different but the Same or the Same but Different? Public Memory of the Second World War in Post-Soviet Lviv," Journal of Modern European History, 9, 3 (2011): 373-394. 